\title{
The Mind-Body Problem: View Outside of the Subject-Object Opposition
}

\author{
Dmitrii V. Konstantinov* \\ Siberian State University of Physical Culture and Sports \\ 244 Maslennikov Str., Omsk, 644009, Russia
}

Received 19.02.2015, received in revised form 03.05.2015, accepted 20.08.2015

\begin{abstract}
The solution of the mind-body problem as the problem of interrelation and interconditionality of mental and physiological faces contradictions when one proceeds from the classical subject-object opposition. Accepting the subject-object opposition only as the convenient way for a scientist to speak about the phenomena of this world (the way that shouldn't be equal to the world itself), it is already senseless to look for the reason of a mental event neither in biology nor in sociality. The subject-object opposition itself is possible, because the event of proportionality of human being and world have happened. In this event the human being and the world are defined by a finite way and until it neither the human being, nor the world can't be defined. The human physiology (as well as a sociality which is sometimes unfairly identified with spirituality) can be considered as a marker of such definiteness, it is minimum of the being of consciousness. However in addition to this minimum there is also another aspect. Indeed, in every act of perception two events are realized simultaneously (not in a sequence): perception of a certain seeming (what is possible if human being and world are already defined, i.e. the act of proportionality of human being and world have happened) and a certain content. The content is always related to a certain idea. Ideas, in its turn, can be subdivided into two classes. To the first we will attribute the ideas which are the result of generalization of preceding experience and which give an opportunity to speak in an ordered way about the phenomena of the surrounding world. But there are also ideas of another sort-those that give an opportunity to the human being to newly re-create himself each time in the complete and ordered state. These ideas organize human life as human one, they are initiated by culture, but they are not a result of generalization. Such are a conscience, good, moral, love and the similar phenomena for which there are no external reasons - here the basis of a phenomenon coincide with the phenomenon itself.

So, human physiology (including work of human brain) is the only side which characterizes the minimum of life of consciousness, it is the marker of human being and world are defined now. We are always after this definiteness (or, more precisely, inside it) when we perceive events of the world, and one shouldn't search the conditions of any event of life of consciousness (the point of interests of ontology) neither in biology nor in sociality. Every conscious act is complete and self-sufficient, and the consciousness basis (being actually the basis of human being) can be found only in consciousness.
\end{abstract}

Keywords: mind-body problem, subject-object opposition, being of consciousness.

DOI: 10.17516/1997-1370-2015-8-11-2474-2484.

Research area: philosophy.

(C) Siberian Federal University. All rights reserved

* Corresponding author E-mail address: konstantinov@sibgufk.ru 


\section{Introduction}

In the first half of the XX century M. Scheler fairly noticed that "in no historical era has the human being become so much of a problem to himself as in ours" (Scheler, 1927/2009, p. 5). Almost a century later it is possible to claim firmly that the problematical character of the human being doesn't disappear anywhere. The discourse about the human being still contains more questions, than answers. One of such questions without an unambigiuous answer is the mind-body problem which can be expressed as follows: how is the work of human consciousness connected with the structure of human brain?

The mind-body problem is considered now from the position of various theoretical approaches. The detailed review of such approaches is provided by K. Ludwig (Ludwig, 2003). Ludwig allocates four statements which, according to his opinion, look plausible, but at the same time can't be true at once because they are contradicting each other: "1 Realism. Some things have mental properties. 2 Conceptual autonomy. Mental properties are not conceptually reducible to non-mental properties, and, consequently, no non-mental proposition entails any mental proposition. 3 Constituent explanatory sufficiency. A complete description of a thing in terms of its basic constituents, their non-relational properties, and relations to one another and to other basic constituents of things, similarly described (the constituent description) entails a complete description of it, i.e., an account of all of a thing's properties follows from its constituent description. 4 Constituent non-mentalism. The basic constituents of things do not have mental properties as such" (Ludwig, 2003, pp. 10-11). Further classification of theoretical approaches to the mind-body problem is built by Ludwig depending on acceptance or non-acceptance of one or another statement listed above. It includes a number of concepts (and their versions): eliminativism, conceptual reductionism, conceptual anti-reductionism, ontological anti-reductionism (Ludwig, 2003, p. 13). Without the purpose to consider each of the designated concepts in detail (Ludwig makes this), we note the following. Without accounting solipsism (universal pure "mental particle theory" in Ludwig's terminology) which Ludwig considers as a kind of realism, all other concepts listed by him are fully laid within two groups allocated earlier by J. Fodor: "Traditional philosophies of mind can be divided into two broad categories: dualist theories and materialist theories. In the dualist approach the mind is a nonphysical substance. In materialist theories the mental is not distinct from the physical; indeed, all mental states, properties, processes and operations are in principle identical with physical states, properties, processes and operations" (Fodor, 1981, p. 124). It seems that such division really reflects the representations developed in modern philosophy.

It must be noted that both dualistic and materialistic approaches face certain difficulties in the explanation of the mind-body problem. At first sight, the materialistic theories are supported by science progress. Indeed, neurobiology in the XX century established that the brain percepts external signals by means of impulse polarization on all neural network, including the brain itself (Hubel, 1988). A variety of specializations of a neural network gives human dimension, in which the direct perception of one outward things is possible by means of sense organs, but it is impossible for other outward things (for example, infrared radiation or ultrasound). Besides, scientists discovered functional asymmetry of cerebral hemispheres. In particular, many researchers pay attention that the left hemisphere of a brain generally carries out abstracting activity, makes operations with abstract and ideal objects, while the work of the right hemisphere correlates with creative thinking 
(Ivanov, 1978; Chernigovskaia \& Deglin, 1986; Geodakian, 1993; Merkulov, 1999; Deglin, 2001; Geodakian, 2005). In turn, T. A. Dobrokhotova and N. N. Bragina assume the interesting thing: the hemispheres of a brain function in the present so that the right hemisphere represents the past and the left hemisphere is involved in conceivableness of the future (Dobrokhotova \& Bragina, 1986). A. N. Parshin draws a conclusion using the research of T. A. Dobrokhotova and N. N. Bragina that "the right hemisphere is more disposed to sensory actions, and the left is disposed to motor actions" (Parshin, 2001, p. 95). On the whole practically all highest mental functions (perception, memory, speech etc.) are implemented by right and left hemispheres differently (Hellige, 1993; The Asymmetrical Brain, 2004).

Thus, the brain functional activity indicates certain somatic pre-conditions of conscious activity of a human being. Philosophers couldn't help being interested in it. As a result the great number of naturalistic concepts of consciousness was created, up to the so-called theory of identity of consciousness and brain according to which the mental event is identical to some event or state in a brain in a literal sense (Priest, 1991). But at the same time even adherents of the theory of identity generally deny that statements about consciousness mean the same as statements about processes in a brain (Priest, 1991, p. 102). There is the gap between the languages describing subjective feelings of a human being and physiological processes in his body, and overcoming of this gap is hardly possible now. In our opinion, T. Nagel characterizes this situation rather precisely: “...We cannot see how a detailed account of what is going on in the brain could exhaustively explain the taste of a cigar - not even if we could see how it explained all the physical effects of such an experience" (Nagel, 1998, p. 343). Let us emphasize that the comprehension of conscious experience is usually understood as a task of philosophy, and the description of brain functions is built in a science discourse. Then it really turns out, as B. V. Markov notes, that "the scientific and philosophical discourses about a human being are incommensurable (our italics. D. K.), herewith a biological knowledge about a human being describes ideal objects as well as philosophical and anthropological doctrines do" (Markov, 1997). Besides, the critics of the theory of identity (and concepts similar to it) point to the fact that the naturalistic hypotheses yield to neither verification nor falsification at the present stage of science progress (Nagel, 1974, pp. 446447). Indeed, still nobody succeeded to catch the content of thought or feeling by means of neurobiology methods.

As for dualism, in our opinion, J. Fodor designates the main difficulty of this approach quite precisely: "The chief drawback of dualism is its failure to account adequately for mental causation. If the mind is nonphysical, it has no position in physical space. How, then, can a mental cause give rise to a behavioral effect that has a position in space? To put it another way, how can the nonphysical give rise to the physical without violating the laws of the conservation of mass, of energy and of momentum?" (Fodor, 1981, p. 124).

\section{Statement of the problem}

It seems that the designated contradictions in both materialistic and dualistic approaches arise because these approaches are based on subject-object opposition, or, in other words, precise defusion of the outside objective world and the subjective image of this world arising in consciousness. However, as it will be shown further, concepts "subjective" and "objective", being habitual and even intuitively clear, are not so obvious as it looks like and require the comprehension. In this case it is possible to agree 
with T. Nagel's critics of thinking conservatism of those philosophy mind agents who try "to reinterpret mental concepts so as to make them tractable parts of the framework of physical science" (Nagel, 1998, p. 347). According to Nagel, "a search for something more unfamiliar, something which starts from the conceptual unintelligibility, in its present form, of the subjective-objective link" is required instead (Nagel, 1998, p. 347). Following this intension, we suppose to uncover sense of the mind-body dualism irrelatively to traditionally understood subject-object opposition. This can be designated as the purpose of our research.

\section{Theoretical framework}

In this work we are guided by the ideas of nonclassical philosophy in which the classical subject-object opposition loses the dominating position. The characteristic tendency of its overcoming in nonclassical philosophy can be expressed, for example, by the following words of E. Husserl: "Everything in the world, everything in space and time is for me by virtue of my experiencing it, my perceiving it, my remembering it, my thinking about it in some way or another, my judging it, my valuing it, my desiring it, and so on. <...> I cannot move into any world, whether by living, experiencing, thinking, valuing or acting, except as it obtains its being and validity in me and from me myself" (Husserl, 1929/2003, p. 6). Such approach requires the construction of another ontology different from the classical subject-object opposition. Although subject-object opposition is strongly fixed in philosophical knowledge and still many philosophical theories are built on it, approach of nonclassical philosophy, according to which the subject and object are defined only in their interaction, seems more reliable to us. From this point of view until the interaction act with the world happened there is no pre-set (with already certain properties) subject of knowledge for whom the observed pre-set world is an external independent object. Such situation looks like it was described by I. A. Bondarenko: "Must be at least one creature executing this minimum of an inclusiveness and if such "included" creature took place, we are already in a certain world (in which something is possible, and something is already impossible). In other words, we are not in a space of potentially possible things, but in this (i.e. defined) world, so defined world (because we could be defined in a different way. In this sense the inquiring about the world in itself is pseudoinquiring)" (Bondarenko, 2002, p. 29).

\section{Methods}

The main philosophical method we use is the phenomenological method. Phenomenology is frequently interpreted as one of philosophical theories. In turn, we (as M. Heidegger) consider the phenomenology from another side - as methodological approach, realizing at the same time that the phenomenology isn't only reduced to methodological procedure. In work "Being and Time" Heidegger emphasizes that "the expression "phenomenology" signifies primarily a concept of method. It does not characterize the "what" of the objects of philosophical research in terms of their content but the "how" of such research" (Heidegger, 1927/1996, p. 24). This "how" assumes, in fact, the researcher's shift of attention from the perceived content to the event of perception something itself. Such change of attention is what they call the phenomenological reduction which allows to see phenomena (that is) with evidence.

\section{Discussion}

As it was stated earlier, the mind-body problem is usually considered in terms of subject-object opposition. Indeed it is possible to agree with D. Hoffman asserting the following: 
practically all mind-body theories are based on the assumption that "a goal of perception is to match or approximate true properties of an objective physical environment" (Hoffman, 2008, p. 92). Hoffman calls this assumption the hypothesis of faithful depiction (HFD), emphasizing its prevalence. However, he doesn't support this hypothesis and offers in exchange the concept of the multimodal user interface (MUI): "I propose that perception is like a multimodal user interface... A successful user interface does not, in general, resemble what it represents. Instead it dumbs down and reformats in a manner useful to the user. Because it simplifies, rather than resembles, a user interface usefully and swiftly informs the actions of the user. The features in an interface usually differ from those in the represented domain, with no loss of effectiveness" (Hoffman, 2008, pp. 93-94). Hoffman visually illustrates this idea by means of comparison of the human being perception with the computer use. For example, if one works with files, he doesn't need to understand all complexity of the processes happening inside the computer. He deals only with the user interface which is "the total reality of the computer" for him (Hoffman, 2008, p. 95). In other words, we make operations with the icons representing application or file. However these operations with the icons don't seem at all those real processes which happen inside the computer. Similar with the perception, but in this case the real situation, unlike an example with the computer, is inaccessible to a human being at all. We are always inside the perception, and can't look at perceived by someone's eyes from the outside.

In this situation there is no sense to look for the mental basis in the physiology which is understood as something external for mental. Division into external and internal, objective and subjective is the abstraction convenient for science. However this abstraction doesn't work if we try to speak about mental basis, i.e. we pass into ontology area. The subject-object opposition itself (as well as any scientific abstractions in general which we constitute by cogitative acts) is possible, because a lot of things have happened already. If one is thinking, he is already in the world available to perception and understanding in the world which can be described by the means of language of the science. This "already" (being fixed in each mental act) can be conditionally designated as the event of proportionality of human being and world in which the first and the second are defined by a finite way and until it neither the human being, nor the world can't be defined. The phrase "by a finite way" supposes here the existence of certain limitations which can't be bypassed. The most important among such limitations is that the event of proportionality itself can't be canceled. If one perceives this item as this item (for example, sees a cup as a cup), he is already irrevocably in the world in which this item is this item here and now, instead of something different. Any reasoning, whether this item is really this item with these properties out of one's perception, doesn't make sense. We already can't consider the world out of human perception after the event of proportionality of human being and world have happened.

If we accept that any ontological description of mental states is possible when the act of proportionality of human being and world have happened already, then this position will lie out of the materialism, idealism or dualism in fact entering the subject-object opposition with the accent on one or another side. At first sight, the approach to the mind-body problem of D. Hoffman looks free from the subject-object opposition. Hoffman, explaining sense of the MUI theory, emphasizes: "MUI theory is not idealism. It does not claim that all that exists are conscious perceptions. It claims that our conscious perceptions need not resemble the 
objective world, whatever its nature is" (Hoffman, 2008, p. 100). However Hoffman offers another theory in further, calling it conscious realism. The conscious realism, according to Hoffman, perfectly complements the MUI theory, but we consider that the first contradicts the second. To see this, it is enough to pay attention to the following statement: "Conscious realism is a proposed answer to the question of what the universe is made of. Conscious realism asserts that the objective world, i.e., the world whose existence does not depend on the perceptions of a particular observer, consists entirely of conscious agents (italics of Hoffman. - D. K.)" (Hoffman, 2008, p. 103). If to be the consistent adherent of the MUI theory and to understand different consciousnesses as conscious agents (Hoffman doesn't explain this term actually), then it is not quite clear by what reason Hoffman can state this. It appears that he makes the same mistake as J. Berkley, when last one asserts that "all those bodies which compose the mighty frame of the world, have not any subsistence without a mind" (Berkley, 1710/1910, p. 32).

Wherein does our position differ from the position of Hoffman or solipsism of Berkley? The only way for us to speak about the world "whose existence does not depend on the perceptions of a particular observer" is rather a scepticism in the manner of Sextus Empiricus, i.e. abstention from judgments about it. Sextus Empiricus, speaking about the qualities of apple, builds the reasoning as follows: "Let us conceive of someone who from birth has touch, smell and taste, but who hears and sees nothing. He will suppose that there is absolutely nothing visible or audible, and that there exist only those three kinds of quality which he is able to grasp. So it is possible that we too, having only the five senses, grasp from among the qualities of the apple only those we are capable of grasping, although other qualities can exist, impressing other sense-organs in which we have no share, so that we do not grasp the objects perceptible by them" (Sextus Empiricus, about $175 / 2000$, pp. 26-27). It is obvious that instead of apple one can speak about any item here. And although at intuitive level the items of the world are thought as something external concerning to our perception, actually we don't know, whether there is a world out of our consciousness and what this world is if it exists. That is why it is difficult for us to agree with the solution of the mind-body problem offered by D. Hoffman. There is nothing that would allow to claim with confidence, as Hoffman does, that "the brain does not cause conscious experience; instead, certain conscious agents, when so triggered by interactions with certain other systems of conscious agents, construct brains (and the rest of human anatomy) as complex icons of their MUIs" (Hoffman, 2008, p. 108). It appears that any scientific or philosophical reasoning on what structure preceding to a mental event generates this event, isn't correct at all. One can speak more or less certain about his experience of consciousness only being in this experience that is directly endured at present as the actual event of his world (being fully honest, it is impossible to assert with confidence the possibility of consciousness experience for other human beings (Nagel, 1987, pp. 19-26)). The attempts to deduce this experience from something external don't make sense - it isn't expressed in the cause-effect relations (the cause-effect relations are the subject of science), it simply is.

How is it possible to interpret mental and physiological connection in this situation? The human physiology (as well as a sociality which is sometimes unfairly identified with spirituality), in our opinion, can be considered as a marker of happening of the event of proportionality of human being and world. It shows that the human being have been defined in this event exactly as the human being, it is the expression of those 
limitations which are imposed on the human being by his dimension. Indeed, each sensible statement about the world (possible so far as the world and the human being have received the definiteness in the event of proportionality) supposes that the human being is biologically alive and socialized (is included in the social relations). This is that related to definiteness of the human being minimum which we have to include to any mental act description, because the state of biological death, experience of an animal or feral people are inaccessible to us and can't be comprehended by us from within as own experience (the non-being situation). In turn, it is possible to consider space and time as a marker of definiteness of the world, as I. Kant. Kant speaks about it in "The Critique of Pure Reason". It is possible to pay attention, for example, to his next phrase: "In the analytical part of the critique it is proved that space and time are only forms of sensible intuition, and therefore only conditions of the existence of the things as appearances" (Kant, 1781/1998, p. 115). Really, the spatio-temporal description of the world is included obviously or unobviously in any our sensible statement about it.

Let us note that it is not enough to have the only minimum designated above (the evidence that world and human being have been defined) for the ontological description of the mental act. Kant understood this perfectly, when he offers the terms "sensibility" and "understanding": "Our cognition arises from two fundamental sources in the mind, the first of which is the reception of representations (the receptivity of impressions), the second the faculty for cognizing an object by means of these representations (spontaneity of concepts); through the former (sensibility. D. K.) an object is given to us, through the latter (understanding. - D. K.) it is thought in relation to that representation (as a mere determination of the mind). Intuition and concepts therefore constitute the elements of all our cognition, so that neither concepts without intuition corresponding to them in some way nor intuition without concepts can yield a cognition" (Kant, 1781/1998, p. 193). Actually Kant says here that in every act of perception two events are realized simultaneously (not in a sequence): event itself and its content. In other words, we, firstly, perceive something, a certain seeming (what is possible if human being and world are already defined, i.e. the act of proportionality of human being and world have happened). Secondly, we perceive this as this, i.e. some content is present. The content is always related to a certain idea. Ideas, in its turn, can be subdivided into two classes. To the first we will attribute the ideas which are the result of generalization of preceding experience and which give an opportunity to speak in an ordered way about the phenomena of the surrounding world. To see a cup as a cup, it is necessary to have the knowledge about a cup, the idea of a cup. This knowledge has additional character in relation to perceived, is not brought out of it.

But there are also ideas of another sort those that give an opportunity to the human being to newly re-create himself each time in the complete and ordered state. These ideas organize human life as human one, they are initiated by culture, but they are not a result of generalization. Such are a conscience, good, moral, love and the similar phenomena for which there are no external reasons - here the basis of a phenomenon coincide with the phenomenon itself. For example, conscience is not a property of the human being or the world, it can't be set through reflexive generalization of empirical acts of the human being. Conscience is what allows to see. If a human being is not in space of conscience, doesn't feel remorse, he doesn't see injustice of his act. Thus conscience can't exists yesterday and can't exist tomorrow, it exists just now, and all at once (there can't be a part of a conscience). Yesterday act in good 
conscience doesn't mean act in good conscience at present. One is compelled to aim each time by own effort to be set in space of conscience (good, love, thought etc.) newly.

So, human physiology (including work of human brain) is the only side which characterizes the minimum of life of consciousness, it is the marker of human being and world are defined now. We are always after this definiteness (or, more precisely, inside it) when we perceive events of the world, and one shouldn't search the conditions of any event of life of consciousness (the point of interests of ontology) neither in biology nor in sociality. Every conscious act is complete and self-sufficient, and the consciousness basis (being actually the basis of human being) can be found only in consciousness. That is why we agree with M. Heidegger asserting the following: "Body, soul, spirit might designate areas of phenomena which are thematically separable for the sake of determinate investigations; within certain limits their ontological indeterminancy might not be so important. But in the question of the being of human being, this cannot be summarily calculated in terms of the kinds of being of body, soul, and spirit which have yet first to be defined. And even for an ontological attempt which is to proceed in this way, some idea of the being of the whole would have to be presupposed" (Heidegger, $1927 / 1996$, p. 45). In our opinion, the use of subject-object opposition destroys this wholeness and doesn't allow to get closer to understanding of the being of thought.

\section{Conclusion}

Summarizing the result, it is possible to say the following. The mind-body problem as the problem of interrelation and interconditionality of mental and physiological arises when one proceeds from the classical subject-object opposition. Accepting the subject-object opposition as the convenient way for a scientist to speak about the phenomena of this world (the way that shouldn't be equal to the world itself), it is already senseless to look for the reason of a mental event out of this event. Mental states are not the data of sense organs received from somewhere outside and processed by a brain (which also plays a part of something separate and independent from conscious act), it is the phenomena understood by themselves. Heidegger was right when said that the "ontological foundations can never be disclosed by subsequent hypotheses derived from empirical material. Rather, they are always already "there" even when that empirical material is only collected" (Heidegger, 1927/1996, p. 46). Life is understood by the life itself, the being is reflected only when we already are in the being.

A sceptic could object here: we can injure the certain lobes of a brain of another human being and see evidently that he is deprived of opportunity to think and understand now. But what does allow to declare it responsibly, except the external manifestations observed by us? We never were into the similar states, they are impenetrable for us at all. T. Nagel characterizes the similar situation when he writes: “...The subjective character of the experience of a person deaf and blind from birth is not accessible to me, for example, nor presumably is mine to him" (Nagel, 1974, p. 440). And herein it is possible to agree with him. However, the assumption that other people can really have consciousness experience which is similar to mine, is a quite appropriate in a certain situation. This assumption can't be subjected to verification or falsification, however in a philosophical discourse it is admissible and even necessary. Such assumption allows me to treat the other as human being (alive, feeling, experiencing), so to keep human in myself.

\section{Acknowledgements}

I thank Aleksandr Lybenko for his invaluable help in the writing this text in English. 


\section{References}

Berkley, G.. A Treatise Concerning the Principles of Human Knowledge: reprint edition. Chicago, The Open Court Publishing Co,1910, xviii, 128 [5] p.

Bondarenko, I. A. Zhizn'soznaniia: konstituirovanie novoi ontologii soznaniia v kul'ture XX veka (Life of Consciousness: Constituting the New Ontology of Consciousness in the Culture of the XX Century). Omsk, Omsk State University, 2002, 320 p.

Chernigovskaia, T. V., Deglin, V. L. (1986). Metaforicheskoe i sillogisticheskoe myshlenie kak proiavlenie funktsional'noi asimmetrii mozga (Metaphorical and Syllogistic Thinking as a Manifestation of Functional Asymmetry of a Brain). Uchenye zapiski Tartuskogo universiteta. Trudy po znakovym sistemam, 19, 68-84.

Deglin, V. L. (2001). Funktsional'naia asimmetria - unikal'naia sposobnost' mozga cheloveka (Functional Asymmetry Is the Unique Ability of Human Brain). Die Metapher und Das Gestalt, 1, available at: http://metaphor.nsu.ru/misc/numl/num1_deglin.htm (accessed 15 June 2014).

Dobrokhotova, T. A., Bragina, N. N. (1986). Printsip simmetrii-asimmetrii v izuchenii soznaniia cheloveka (The Principle of Symmetry-Asymmetry in Examination of Human Consciousness). Voprosy Filosofii, 7, 13-27.

Fodor, J. A. (1981). The Mind-Body Problem. Scientific American, 244 (1), 124-132.

Geodakian, V. A. (1993). Asinkhronnaia asimmetria (Asynchronous Asymmetry). Zhurnal vysshei nervnoi deiatel'nosti, 43 (3), 543-561.

Geodakian, V. A. (2005). Evoliutsionnye teorii asimmetrizatsii organizmov, mozga i tela (Evolutionary Theories of Asymmetrization of Organisms, Brain and Body). Uspekhi fiziologicheskikh nauk, 36 (1), 24-53.

Heidegger, M. Being and Time (translated by J. Stambaugh). Albany, State University of New York Press, 1996. xix, 487 p.

Hellige, J. B. Hemispheric Asymmetry: What's Right and What's Left. Cambridge, MA, Harvard University Press, 1993, 396 p.

Hoffman, D. (2008). Conscious Realism and the Mind-Body Problem. Mind and Matter, 6 (1), $87-121$.

Hubel, D. H. Eye, Brain, and Vision. N. Y., W. H. Freeman, 1988, - 241 p.

Husserl, E. Introduction to Transcendental Phenomenology (translated by C. Welch). Sackville, Atcost Press, 2003, 37 p.

Ivanov, V. V. Chet i nechet: asimmetriia mozga i znakovykh sistem (Even and Uneven: Asymmetry of a Brain and Sign Systems). Moscow, Sovetskoe radio, 1978, 184 p.

Kant, I. The Critique of Pure Reason (edited and translated by P. Guyer, A. W. Wood). Cambridge, Cambridge University Press, 1998, 785 p.

Ludwig, K. The Mind-Body Problem: An Overview. The Blackwell Guide to the Philosophy of Mind. Oxford, Blackwell, 2003, pp. 1-46.

Markov, B. V. (1997). Filosofskaia antropologiia: ocherki istorii i teorii (Philosophical Anthropology: History and Theory Studies). St. Petersburg, Lan'. 380 p. Available at: http:// anthropology.ru/ru/texts/markov/fantr.html (accessed 27 June 2014).

Merkulov, I. P. Kognitivnaia evoliutsiia (Cognitive Evolution). Moscow, ROSSPEN, 1999, $310 \mathrm{p}$. 
Nagel, T. (1974). What Is It Like to Be a Bat? The Philosophical Review, 83 (4), 435-450.

Nagel, T. What Does It All Mean? A Very Short Introduction to Philosophy. N. Y., Oxford, Oxford University Press, 1987, - 112 p.

Nagel, T. (1998). Conceiving the Impossible and the Mind-Body Problem. Philosophy, 73 (285), 337-352.

Parshin, A. N. (2001). Dopolnitel'nost' i simmetriia (Complementarity and Symmetry). Voprosy Filosofii, 4, 84-104.

Priest, S. Theories of the Mind. London, Penguin Books, 1991, 256 p.

Scheler, M. The Human Place in the Cosmos (translated by M. Frings). Evanston, Northwestern University Press, 2009, xxii, 79 p.

Sextus Empiricus. Outlines of Scepticism (edited by J. Annas and J. Barnes). Cambridge, Cambridge University Press. 2000, xxxv, 248 p.

The Asymmetrical Brain. Cambridge, MA, The MIT Press, 2004, - 796 p.

\title{
Проблема психофизиологического дуализма:
} взгляд вне субъектно-объектной оппозиции

\author{
Д.В. Константинов \\ Сибирский государственный университет \\ физической культуры и спорта \\ Россия, 644009, Омск, ул. Масленникова, 144
}

\begin{abstract}
Решение проблемы психофизиологического дуализма как проблемы взаимосвязи и взаимообусловленности ментального и физиологического приводит к противоречиям, если исходить из классического субъект-объектного противопоставления. Если же принять, что субъект-объектная оппозиция - это просто удобный для учёного способ говорения об явлениях этого мира, который не надо отождествлять с миром, то причину ментального события уже бессмысленно искать в физиологическом или соииальном. Сама субъектно-объектная оппозииия возможна тогда, когда уже произошло событие соразмерности человека и мира событие, в котором человек и мир определяются конечным образом и до которого ни человек, ни мир не могут быть определены. Маркером такой определённости со стороны человека и является его физиология (как и соииальность, которую порой неоправданно отождествляют c духовностью), это минимум бытия сознания. Однако помимо этого минимума есть и другая сторона. Действительно, в каждом акте восприятия реализовано одномоментно (не в последовательности) два события: восприятие некой явленности (что возможно, если человек и мир уже определены, т. е. произошёл акт соразмерности человека и мира) и какого-то содержания. Содержание всегда связано с определённой идеей. Идеи, в свою очередь, можно подразделить на два класса. К первому мы относим то, что является результатом обобщения предшествующего опыта и даёт возможность упорядоченным образом говорить о явлениях окружающего мира. В свою очередь, ко второй группе можно отнести те идеи, которые дают возможность человеку каждый раз заново воссоздавать в иелостном и упорядоченном виде самого себя. Эти идеи организуют человеческую жизнь в качестве человеческой, они инициируются культурой, но они - не результат обобщения. Таковы совесть, добро, нравственность, любовь и тому подобные феномены, для которых нет внешних причин -здесь условия вещи совпадают с самой вещьюю.
\end{abstract}


Итак, биологическое в человеке (в том числе работа его мозга) - это лишь та сторона, которая характеризует минимум бытия сознания, это маркер того, что человек и мир теперь определены. Mbl, воспринимая события мира, всегда находимся уже после этой определённости (или, точнее сказать, в ней), и причины любого события жизни сознания (сфера интересов онтологии) следует искать уже отнюдь не в биологии или социальности. Каждый сознательный акт иелостен и самодостаточен, и основания сознания (являюшиеся фактически основаниями человека) можно найти только в самом сознании.

Ключевые слова: проблема психофизиологического дуализма, субъектно-объектная оппозиция, бытие сознания.

Научная спещиальность: 09.00.00. - философские науки. 